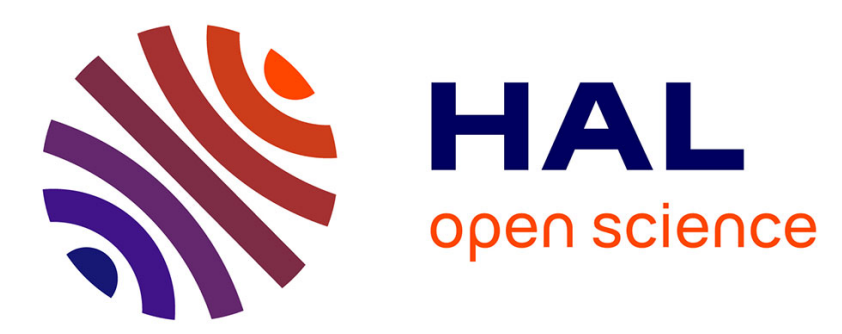

\title{
Tracing cadmium contamination kinetics and pathways in oysters (Crassostrea gigas) by multiple stable Cd isotope spike experiments
}

Emilie Strady, Jörg Schäfer, Magalie Baudrimont, Gérard Blanc

\section{- To cite this version:}

Emilie Strady, Jörg Schäfer, Magalie Baudrimont, Gérard Blanc. Tracing cadmium contamination kinetics and pathways in oysters (Crassostrea gigas) by multiple stable Cd isotope spike experiments. Ecotoxicology and Environmental Safety, 2011, 74 (4), pp.600-606. 10.1016/j.ecoenv.2010.10.020 . hal-02357365

\section{HAL Id: hal-02357365 https://hal.science/hal-02357365}

Submitted on 14 Nov 2019

HAL is a multi-disciplinary open access archive for the deposit and dissemination of scientific research documents, whether they are published or not. The documents may come from teaching and research institutions in France or abroad, or from public or private research centers.
L'archive ouverte pluridisciplinaire HAL, est destinée au dépôt et à la diffusion de documents scientifiques de niveau recherche, publiés ou non, émanant des établissements d'enseignement et de recherche français ou étrangers, des laboratoires publics ou privés. 


\title{
Tracing cadmium contamination kinetics and pathways in oysters (Crassostreagigas) by multiple stable $\mathrm{Cd}$ isotope spike experiments
}

\author{
Emilie Strady ${ }^{\mathrm{a}, \mathrm{n}}$, b̈rg Schäfer ${ }^{\mathrm{a}, \mathrm{n}}$, Magalie Baudrimont ${ }^{\mathrm{b}}$, Gérard Blanc ${ }^{\mathrm{a}}$ \\ a Universite' de Bordeaux, UMR EPOC 5805, GEMA Team Av. des Faculte's, 33405 Talence, France \\ b Universite' de Bordeaux, UMR EPOC 5805, Place du Dr B. Peyneau, 33120 Arcachon, France
}

\section{a r t ic le in fo}

\section{Article history:}

Received 20 May 2010

Received in revised form

6 October 2010

Accepted 9 October 2010

Available online 28 October 2010

Keywords:

Crassostrea gigas

Cadmium

Stable isotope spiking

Trophic direct contamination

\begin{abstract}
a b s t r a c t
Laboratory experiments using stable $\mathrm{Cd}$ isotopes $\left({ }^{110} \mathrm{Cd}\right.$ and $\left.{ }^{112} \mathrm{Cd}\right)$ were conducted to separately and simultaneously characterize Cd accumulation in different tissues of Pacific oysters (Crassostrea gigas) via the (i) trophic and (ii) direct pathways. For this, we exposed juvenile oysters to ${ }^{110} \mathrm{Cd}$-spiked seawater $\left({ }^{110} \mathrm{Cd}: 2 \mathrm{mg} 1^{-1}\right.$; constant level) and ${ }^{112} \mathrm{Cd}$-spiked food (Thalassiossera weissflogii, ${ }^{112} \mathrm{Cd}$ : $2 \mathrm{mg} 1^{-1}$ in $35 \sim 10^{3}$ cells/oyster/L) in four experimental treatment groups, each containing 6 oysters, for 21 days with constant trophic feeding. These Cd contamination levels were $\sim 10$ times lower than those typically used in experimental accumulation studies. Three oysters per treatment group were dissected every 7 days with separate sampling of the gills, digestive gland and the rest of the body. Metallothioneins were analysed in the digestive gland and gills. Cadmium concentrations and isotope ratios were measured in water (daily) and tissues (weekly) by GF-AAS and ICP-MS. The observed time-dependant evolution in Cd concentrations and ${ }^{110} \mathrm{Cd} /{ }^{114} \mathrm{Cd}$ and ${ }^{112} \mathrm{Cd} /{ }^{114} \mathrm{Cd}$ isotope ratios clearly revealed the bio-accumulation short-term kinetics and pathways of Cd contamination in the different tissues. Under the experimental conditions, significantly changed isotope ratios in gills and the digestive gland of oysters suggested rapid and efficient contamination by ${ }^{110} \mathrm{Cd}$ derived from direct exposure followed by internal $\mathrm{Cd}$ transfer between organs. Trophic contamination became measurable after 14 days of exposure corresponding to a trophic transfer rate of $1 \%$. Constant metallothionein levels during the experiment suggested that the initially present metallothionein levels were sufficient to deal with the experimental Cd exposure.
\end{abstract}

\section{Introduction}

Oyster cultures are economically important in coastal areas. Oysters are filter-feeding bivalves that easily accumulate trace metals, especially cadmium (Baudrimont et al., 2005; Lekhi et al., 2008; Bendell and Feng, 2009; Christie and Bendell, 2009; Ng et al., 2010). Due to known human health effects (Bragigand et al., 2004; Cheng and Gobas, 2007; Copes et al., 2008; Widmeyer and BendellYoung, 2008; Saratug et al., 2010), consumption of oysters has been limited to $5 \mathrm{mg} \mathrm{g}^{-1} \mathrm{dw}$ in Europe (CE No. 466/2001). Oyster production and selling have thus become restricted to regions where cadmium oyster concentrations are below this amount. Thus, detailed knowledge of the mechanisms underlying $\mathrm{Cd}$ accumulation by the oyster is needed such that possibleremediation strategies can be implemented.

Experimental studies of $\mathrm{Cd}$ bio-accumulation in oysters using radiolabelled isotope analysis have shown that contamination may occur via direct (metal uptake by the gill epithelium of the dissolved

\footnotetext{
${ }^{\mathrm{n}}$ Corresponding authors.

E-mail addresses: e.strady@epoc.u-bordeaux1.fr (E. Strady), i.schaefer@epoc.u-bordeaux1.fr (J. Scha"fer).
}

metal from the water column) and trophic (metal uptake by the digestive apparatus of metal associated to nutritive particles) pathways (Reinfelder et al., 1997; Boisson et al., 2003). This technique is very sensitive at low contamination levels, but the analytical constraints and the authorisations required to use radiolabelled isotopes make this technique inaccessible to non-labelled laboratories. Thus, most experimental studies of trace metal contamination of marine organisms are based on dose-response experiments where exposure levels typically are orders of magnitude higher than real environmental conditions, for example in recent literature (Brinza et al., 2009; Nadella et al., 2009). Globally, such high metal exposure levels facilitate both measuring bio-accumulation and control exposure levels in seawater and detecting ecotoxicological responses to contamination with respect to sensitivity of currently applied analytical techniques such as atomic absorption spectrometry (AAS) or mass spectrometry (MS). Furthermore, analysing dissolved metals in seawater to continuously adjust exposure level during the experiment requires specific techniques and protocols to control/limit saline matrix effects, e.g. by dilution, liquid/liquid or solid/liquid extraction before AAS and MS measurements (Danielsson et al., 1982; Dabrin et al., 2009; Strady et al., 2009). Accordingly, the experimental metal exposure level may depend on analytical performances and the chosen metal exposure levels typically have been much higher than environmental values and open 
to criticism. In this context, we based Cd contamination experiments on single stable isotope enrichment and Inductively Coupled Plasma Mass Spectrometry (ICP-MS) measurements as previously studied in freshwater (Croteau and Luoma, 2007; Croteau et al., 2007; Komjarova and Blust, 2008). We improved this method by (i) developing multiple stable $\mathrm{Cd}$ isotope enrichment to trace simultaneously both contamination pathways and (ii) in estuarine and marine waters after removal of the saline matrix by solid-liquid extraction. This approach aimed at using close-to environment exposure levels to (i) simultaneously trace different contamination pathways in the marine environment, (ii) determine the respective kinetics and (iii) identify related detoxification processes using protein responses.

The objective of the present work was to explore the potential of multiple stable $\mathrm{Cd}$ isotope spikes to simultaneously trace accumulation kinetics and pathways in gills, digestive glands and the rest of the oyster tissues exposed to direct or/and trophic contamination. For this, we exposed juvenile oysters to seawater and algae spiked with single $\mathrm{Cd}$ stable isotopes (e.g. ${ }^{110} \mathrm{Cd}$ in seawater and ${ }^{112} \mathrm{Cd}$ in algae) at levels only $\sim 10$ times higher than typical mid-salinity values in the Gironde Estuary (Dabrin et al., 2009), for three weeks. In fact we referenced the exposure level of the experiment to the historic polymetallic polluted Gironde Estuary (Boutier et al., 1989; Jouanneau et al., 1990; Lapaquellerie et al., 1995; Audry et al., 2007), where oyster farming has been forbidden because of high $\mathrm{Cd}$ contents measured in wild oysters (Boutier et al., 1989). We report and discuss time-resolved $\mathrm{Cd}$ accumulation in organs and the rest of the tissues obtained from changes in isotope ratios over time and on metallothionein levels observed. Finally, the role of direct and trophic pathways in the observed accumulation patterns is discussed.

2. Materials and methods

\subsection{Oysters}

Juvenile Pacific oysters (18 months old, $4 \mathrm{~cm}$ shell length, Crassostrea gigas) were coming from a farming activity in the uncontaminated area, the Arcachon Bay France (Marie, 2005). We selected 72 oysters with similar weight and shape, and introduced six of them in each experimental treatment $(10 \mathrm{~L}$ synthetic seawater, salinity $15,[\mathrm{Cd}]^{1 / 4} 30 \mathrm{ng} \mathrm{L}^{-1}$; Instant Ocean $^{\text {s) }}$ two days before the contamination experiment and without feeding for acclimatising.

\subsection{Experimental conditions}

Direct and trophic pathways were traced by spiking seawater and algae with stable cadmium isotopes, ${ }^{110} \mathrm{Cd}$ and ${ }^{112} \mathrm{Cd}$, respectively (Assays, atomic percent $97.36 \%$ and $98.27 \%$, respectively). Seawater, initially Cd concentrated at $0.07 \mathrm{mg} \mathrm{L}^{-1}$, was ${ }^{110} \mathrm{Cd}$-spiked at $2 \mathrm{mg} \mathrm{L}^{-1}{ }_{3}$ All oysters were fed daily with Thalassiosira weissflogii at a constant level $(35 \sim 10$ cells oyster L, counting by Nageotte chamber) close to environmental conditions (e.g. Marennes-Ole ron Bay, Malet et al., 2008; Thau Lagoon, Dupuy et al., 2000). Algae for trophic characterisation were ${ }^{112} \mathrm{Cd}-$ spiked at $2 \mathrm{mg} \mathrm{L}^{-1}$ for $200 \sim 10^{3}$ cells $\mathrm{L}^{-1}, 48 \mathrm{~h}$ before being fed to the oysters, and were added to the experimental treatments every two days. The algae were grown in the laboratory in specific chambers containing enriched nutrient medium. $\mathrm{Cd}$ concentrations in the algae were determined by substituting the [Cd] in the filtered water where the algae were contaminated to the initial [Cd] added, as the algae dry weight was too low.

Globally, this feeding rate was sufficient to produce faeces and pseudo-faeces, which were collected with a Pasteur syringe, dried and kept at $4 \mathrm{C}$ in the dark. Thus, six oysters per treatment were exposed to four conditions in three replicate treatments (Fig. 1): (1) Control, C; (2) $\mathrm{SW}^{110} \mathrm{Cd}: 2 \mathrm{mg} \mathrm{L}^{-1}$, enriched seawater representing the direct pathway; (3) $\mathrm{A},{ }^{112} \mathrm{Cd}: 2 \mathrm{mg} \mathrm{L}^{-1}$ for $200 \sim 10^{3}$ cells $\mathrm{L}^{-1}$, enriched algae representing the trophic pathway and (4) SWA, enriched seawater and algae, representing both direct $\left({ }^{110} \mathrm{Cd}: 2 \mathrm{mg} \mathrm{L}^{-1}\right)$ and trophic $\left({ }^{112} \mathrm{Cd}: 2 \mathrm{mg} \mathrm{L}^{-1}\right.$ for $200 \sim 10$ cells $\overline{\mathrm{L}}$ ) pathways.

\subsection{Water control}

During experiments, ${ }^{110} \mathrm{Cd}$ concentrations were adjusted daily to $2 \mathrm{mg} \mathrm{L}^{-1}$ after Cd determination by GF-AAS (Solaar Thermo; Pd $2 \mathrm{~g} \mathrm{~L}^{-1}$ and $\mathrm{Mg} 1 \mathrm{~g} \mathrm{~L}^{-1}$ matrix

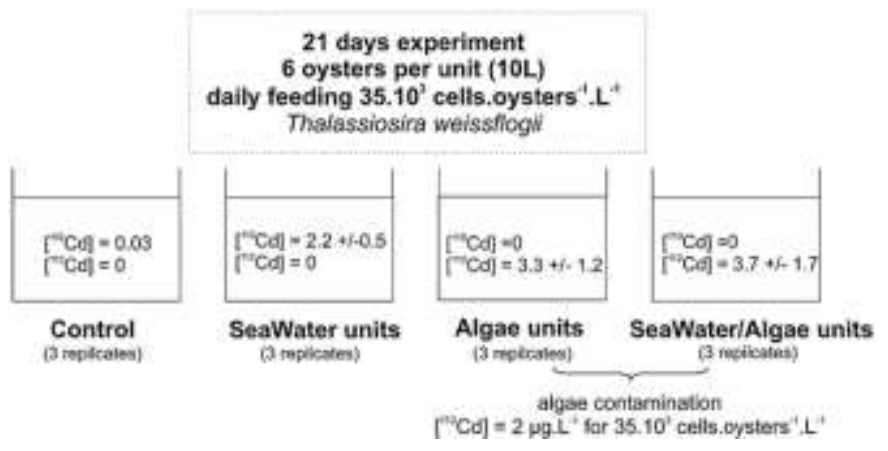

Fig. 1. Experimental procedure. The $\left[{ }^{110} \mathrm{Cd}\right]$ and $\left[{ }^{112} \mathrm{Cd}\right]$ values represent the mean $\left[{ }^{110} \mathrm{Cd}\right]$ and $\left[{ }^{112} \mathrm{Cd}\right]$ measured in seawater units over the 21 days of experiment. To notice, concentrations attempted in seawater units were $\left[{ }^{110} \mathrm{Cd}\right]{ }^{1 / 4} 2 \mathrm{mg}^{-1}$ and $\left[{ }^{112} \mathrm{Cd}\right]^{1 / 4} \mathrm{O} \mathrm{mg} \mathrm{l}^{-1}$.

modifiers, 10-fold dilution). Physico-chemical parameters were controlled daily and kept at constant level: salinity 1570.3, temperature $151 \mathrm{C} 71 \mathrm{lC}, \mathrm{pH} 8.370 .2$ and $\mathrm{O}_{2}(100 \%$ saturation) via an oxygen diffuser. The light conditions employed were $12 \mathrm{~h}$ per day under lighting and in the dark. Furthermore, $60 \mathrm{~mL}$ of seawater was sampled daily in every treatment, acidified $\left(\mathrm{HNO}_{3} \mathrm{Ultrex}, 2 \%\right)$, stored at $4 \mathrm{C}$ in the dark, and dissolved metal was pre-concentrated and separated from the salt matrix by solid-liquid extraction (DigiSEP blue cartridges, SCP Science, functional group amino di acetate; Strady et al, 2009) prior to ICP-MS measurements (Thermo X7). This robust method provided very good reproducibility (o 3\%) and accuracy ( $05 \%$ ) of certified seawater (CASS-4: NASS-5) and also of Milli- $Q^{s}$ water enriched with ${ }^{110} \mathrm{Cd}$ and ${ }^{112} \mathrm{Cd}$.

\subsection{Metal and metallothionein quantification in oyster tissues}

Two oysters per treatment (or replicate) were removed before starting the experiment (T0) and after 7 days (T7), 14 days (T14) and 21 days (T21) of exposure. Each oyster was immediately dissected and separated into three parts: gills $(G)$, digestive gland (DG) and the rest of the body (R). Aliquots representing $2 / 3$ of $G$ and DG masses and the whole R were kept at $-201 \mathrm{C}$ for metal analysis. Then they were weighed, dried at $85 \mathrm{lC}$ for $24 \mathrm{~h}$, weighed again, mineralised for $3 \mathrm{~h}$ in $3 \mathrm{~mL} \mathrm{HNO}_{3}$ at $1001 \mathrm{C}$ (DigiPREP, ${ }^{\mathrm{s}}$ SCP Sciences) and the solution obtained was stored at $4 \mathrm{1C}$ in the dark until analysis by GF-AAS (Thermo Solaar; using Pd $2 \mathrm{~g} \mathrm{~L}^{-1}$ and $\mathrm{Mg} 1 \mathrm{~g} \mathrm{~L}^{-1}$ matrix modifiers) and by ICP-MS (Thermo $\sim$ X7). The other aliquots representing $1 / 3$ of the $G$ and DG mass were stored at $-801 \mathrm{C}$ under $\mathrm{N}_{2}$-atmosphere until metallothionein (MT) analysis by the mercury-saturation-assay described by Marie et al. (2006a) and using cold inorganic mercury.

\subsection{Cadmium concentrations and stable isotope ratios in oysters by ICP-MS}

Oyster tissue digestates were measured by Inductively Coupled Plasma-Mass Spectrometry (ICP-MS; Thermo X7). As stable isotopes were added to seawater $\left({ }^{1} \mathrm{Cd}\right)$ and algae $\left({ }^{1} \mathrm{C}^{2} \mathrm{~d}\right)$ to trace contamination pathways, we used external calibration with a Cd elemental solution (SCP Sciences ${ }^{\mathrm{s}}$ ) calibration and did all of our calculations from isotope dwell counts (Croteau et al., 2004) according to the following equations expressed for ${ }^{112} \mathrm{Cd}$ isotope and transposable to ${ }^{110} \mathrm{Cd}$. Firstly, we determined the isotope ratios $\left({ }^{112 / 114} \mathrm{Cd}\right)_{\mathrm{m}}$ in samples which correspond to the dwell counts of spiked isotope over the reference isotope td

$\delta^{112=114} \mathrm{CdP}_{\mathrm{m}}{ }^{1 / 4} \delta^{112} \mathrm{CdP}_{\mathrm{m}}=\chi^{114} \mathrm{CdP}_{\mathrm{m}}$

where $\left({ }^{112} \mathrm{Cd}\right)_{\mathrm{m}}$ and $\left({ }^{114} \mathrm{Cd}\right)_{\mathrm{m}}$ represent the measured counts for ${ }^{112} \mathrm{Cd}$ and ${ }^{114} \mathrm{Cd}$ isotopes.

Total Cd concentration in the samples was calculated from the mono-isotopic Cd concentrations $\left({ }^{112} \mathrm{Cd}\right)$ as the sum of the natural concentrations derived from natural isotopes and the additional concentrations accumulated from the spikes (Eqs. (2) and (3)).

$\left.\left.\left.1 / 2{ }^{112} \mathrm{Cd}\right]^{1 / 4}{ }^{1 / 2}{ }^{112} \mathrm{Cd}\right]_{\mathrm{n}} \mathrm{p}^{1 / 2}{ }^{112} \mathrm{Cd}\right]_{\mathrm{s}}$

where $\left[{ }^{112} \mathrm{Cd}\right]_{n}$ and $\left[{ }^{112} \mathrm{Cd}\right]_{s}$ represent natural and spiked ${ }^{112} \mathrm{Cd}$ concentrations in the samples.

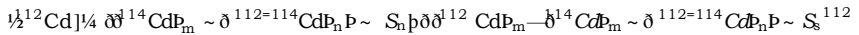

where $\left({ }^{112 / 114} \mathrm{Cd}\right)_{n}$ represents natural isotope ratios, $S_{n}$ and $S_{\mathrm{s}}$ represent, respectively, the slopes of the natural isotopic abundance calibration curves and of the modified (spiked) isotopic abundance calibration curves. 
However, one cannot exclude that ${ }^{112} \mathrm{Cd}$ from spiked algae was present in the seawater of the A (enriched algae) and SWA (enriched seawater and algae) treatments (concentrations very close to ${ }^{110} \mathrm{Cd}$ ), contributing ${ }^{112} \mathrm{Cd}$ to direct contamination. Thus, we corrected this potential ${ }^{112} \mathrm{Cd}$ direct contamination from the ${ }^{110} \mathrm{Cd}$ direct signal, in $\mathrm{A}$ and SWA treatments, using the following equations (expressed for SWA and transposable to A treatments):

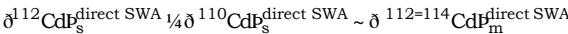

where $\left({ }^{112} \mathrm{Cd}\right)_{\mathrm{s}}$ direct $\mathrm{SWA}$ is the ${ }^{112} \mathrm{Cd}$ direct pathway counts in SWA treatments, $\left({ }^{112} \mathrm{Cd}\right)_{\mathrm{s}}^{\mathrm{direct} \text { SWA }}$ is the ${ }^{110} \mathrm{Cd}$ direct pathway counts in SWA treatments, and $\left({ }^{112 / 114} \mathrm{Cd}\right)_{\mathrm{m}}^{\text {directsWA }}$ is the measured isotope ratios in SWA treatments.

Thus, in SWA treatments, $\left({ }^{112 / 114} \mathrm{Cd}\right){ }^{\mathrm{SWA}}$ isotope ratios were determined according to

$\partial^{112=114} \mathrm{CdP}_{\mathrm{m}}^{\mathrm{SWA}}{ }^{1 / 4} \partial \partial^{112} \mathrm{CdP}_{\mathrm{m}^{-}}{ }^{112} \mathrm{CdP}_{\mathrm{s}}^{\text {direct }} \mathrm{SWA}_{\mathrm{P}=\partial}^{114} \mathrm{CdP}_{\mathrm{m}}$

Accordingly, $\left[{ }^{112} \mathrm{Cd}\right]$ in SWA treatments was determined from Eq (2) by substituting $\left[{ }^{112} \mathrm{Cd}\right]^{\text {direct }}$, as follows:

$\left.{ }_{1 / 2}^{112} \mathrm{Cd}\right]^{\mathrm{SWA}}{ }_{1 / 4} \gamma^{114} \mathrm{CdP}_{\mathrm{m}} \sim \partial^{112=114} \mathrm{CdP}_{\mathrm{n}} \mathrm{P} \sim \mathrm{S}_{\mathrm{n}}$ pðð ${ }^{112} \mathrm{CdP}_{\mathrm{m}}$

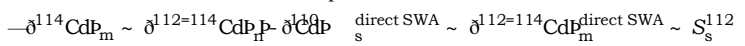

Finally, Cd concentration in SWA treatments was calculated using both ${ }^{110} \mathrm{Cd}$ and ${ }^{112} \mathrm{Cd}$ isotope concentrations according to the following equation:

$\left.\left.1 /[\mathrm{d}]^{\mathrm{SWA}}{ }_{1 / 4^{1 / 2}}^{110} \mathrm{Cd}\right]_{\mathrm{s}}^{\mathrm{SWA}} \mathrm{p}^{1 / 2}{ }^{112} \mathrm{Cd}\right]^{\mathrm{SWA}}$

ð7P

\subsection{Statistical analysis}

We first checked the normality and homogeneity of error terms. When these assumptions were achieved (e.g. bio-accumulation and metallothionein), the significant effect of factors taken into account was analysed using a variance method (ANOVA) and a least square deviation test (LSD). When assumptions were not respected (e.g. isotope ratios), a non-parametric method was performed using the Kruskall-Wallis test. For all statistical results, a probability of p00.05 was considered significant.

\section{Results}

\subsection{Experimental conditions}

Cadmium concentrations were measured daily in all experimental treatments (Fig. 1). In C treatments, concentrations were low and constant over the experiment (Fig. 1). In SW treatments, Cd concentrations varied with a mean of $2.270 .5 \mathrm{mg} \mathrm{L}^{-1}$ (Fig. 1). In A and SWA treatments, GF-AAS measurements revealed Cd concentrations higher than expected. Simultaneous measurements by ICP-MS showed enrichment in ${ }^{112} \mathrm{Cd}$ in $\mathrm{A}$ and SWA treatments, probably originating from release of ${ }^{112} \mathrm{Cd}$ from contaminated algae. Thus, $\mathrm{Cd}$ concentrations in seawater were calculated from the ${ }^{112} \mathrm{Cd}$ isotope (Eq. 7) in A and SWA treatments (Fig. 1).

\subsection{Cadmium isotope ratios in oyster tissues}

Time-dependent evolution of $\mathrm{Cd}$ isotope ratios ${ }^{110} \mathrm{Cd} /{ }^{114} \mathrm{Cd}$ and ${ }^{112} \mathrm{Cd} /{ }^{114} \mathrm{Cd}$ in gills, digestive gland and the rest of the body were measured for the different experimental conditions after 7, 14 and 21 days of exposure (Kruskall-Wallis test, $p$ o0.05; Fig. 2). The ${ }^{110} \mathrm{Cd} /{ }^{114} \mathrm{Cd}$ ratio, characterizing direct contamination, significantly changed after 7 days of exposure in gills, digestive glands and in the rest of the tissues for the SW and SWA treatments (Fig. 2a, c, e). After 21 days, ${ }^{110} \mathrm{Cd} /{ }^{114} \mathrm{Cd}$ ratios in gills from $\mathrm{A}$ and SWA were significantly higher than in digestive glands and the rest of the tissues. In contrast, trophic contamination characterised by ${ }^{112} \mathrm{Cd} /{ }^{114} \mathrm{Cd}$ ratios became significantly measurable after 14 days of exposure in gills, digestive glands and the rest of the tissues for the A and SWA treatments (Fig. $2 \mathrm{~b}, \mathrm{~d}, \mathrm{f}$ ). After 21 days, the ${ }^{112} \mathrm{Cd} /{ }^{114} \mathrm{Cd}$ ratios in gills and digestive glands were similar in magnitude.

\subsection{Cadmium isotope ratios in faeces and pseudo-faeces}

Since oysters did not regularly produce faeces $(\mathrm{F})$ and pseudofaeces $(\mathrm{PF})$, we could not collect them daily in every treatment. Thus, we grouped $\mathrm{F}$ and $\mathrm{PF}$ of the three replicate treatments and compared their isotope composition to those of the Control treatment sampled the same day or within the same few-days interval, when the production was too low. The ${ }^{110} \mathrm{Cd} /{ }^{114} \mathrm{Cd}$ ratios in $\mathrm{F}$ and $\mathrm{PF}$ changed rapidly (after 3 days of exposure) and showed significantly higher enrichment in PF than in F (Kruskall-Wallis
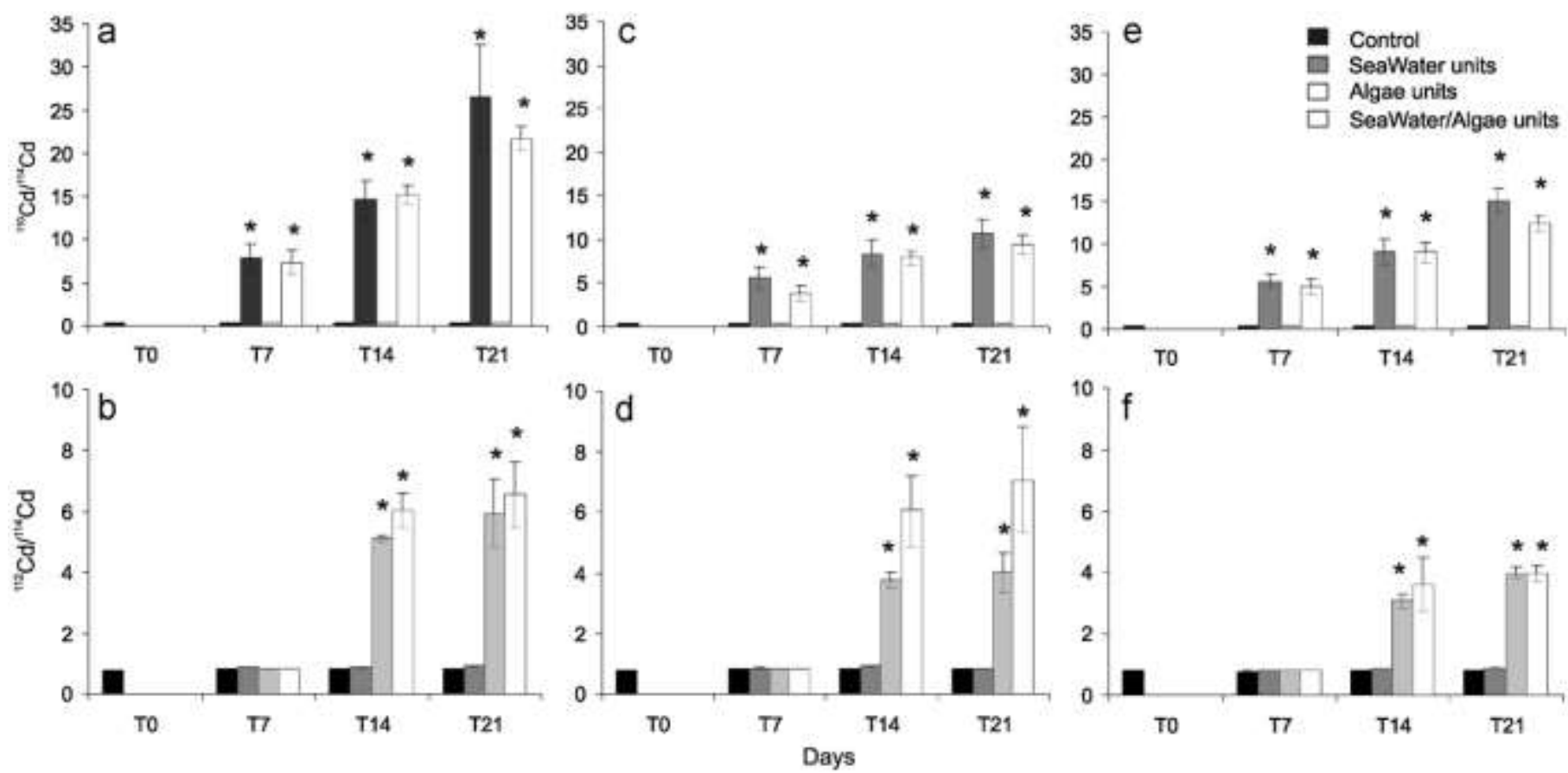

Fig. 2. Stable Cd isotopes ratio variations $\left({ }^{110} \mathrm{Cd} /{ }^{114} \mathrm{Cd}\right.$ and ${ }^{112} \mathrm{Cd} /{ }^{114} \mathrm{Cd}$, mean $7 \mathrm{SEM}, n^{1 / 4} 3$ ) in gills (a, b), digestive glands (c, d) and rests of bodies (e, f) over experiment from Controls units (black area), SeaWater units (dark grey area), Algae units (light grey area) and SeaWater/Algae units (white area). Stars indicates the significance ( $p \circ 0.05$, Kruskall-Wallis test). 
test, $p 00.05$; Fig. 3a). Higher variations occurred in $\mathrm{F}$ and $\mathrm{PF}$ from SW treatments than from SWA treatments (Fig. 3a). ${ }^{112} \mathrm{Cd} /{ }^{114} \mathrm{Cd}$ ratios in $\mathrm{F}$ and $\mathrm{PF}$ varied rapidly, significantly and with the same amplitude in A and SWA treatments (Fig. 3b). However, measured ${ }^{112} \mathrm{Cd} /{ }^{114} \mathrm{Cd}$ ratios were higher in $\mathrm{F}$ than in PF.

\subsection{Cadmium bio-accumulation in oyster tissues}

$\mathrm{Cd}$ concentrations in oyster tissues were measured by ICP-MS and bio-accumulation was calculated from $\mathrm{Cd}$ stable isotope enrichment (see Section 2). Thus, we calculated both direct $\left({ }^{110} \mathrm{Cd}\right)$ and trophic $\left({ }^{112} \mathrm{Cd}\right)$ contamination in the gills, digestive gland and rest of the body from the respective excess isotopes and corrected the data for ${ }^{112} \mathrm{Cd}$ stable isotope accumulated by the direct pathway in A and SWA treatments according to Eq. (7) (Fig. 4).

Cadmium concentrations in gills, digestive glands and the rest of the tissues from Control oysters were constant over time (Fig. 4ac). After 21 days, concentrations were significantly higher in all tissues of oysters from SW and SWA treatments than in those from A treatments (ANOVA $p$ 00.05; Fig. $4 a-c$ ). From T14 to T21, Cd accumulated more efficiently in digestive glands than in gills, and accumulation in the rest of the body slightly increased (Fig. 4). In fact, bio-accumulation in gills, which are the most exposed tissues to the direct pathway, was 2-fold and 6-fold higher than in Control oysters after 7 days and 21 days of exposure, respectively (Fig. 5). Furthermore, final $\mathrm{Cd}$ concentrations in gills and digestive glands were similar and tended to be higher than in the rest of the tissues.

\subsection{Metallothionein levels}

Metallothionein (MTs) levels in oysters were measured in gills and digestive glands at the beginning (T0) and the end (T21) of the experiment for all treatments (Fig. 5). After 21 days, MT concentrations in gills and digestive glands of oysters from the SW, A and SWA treatments were not significantly different from those in gills and digestive glands of Control oysters (ANOVA $p$ 00.05; Fig. 5a, b).

\section{Discussion}

\subsection{Stable isotope enrichment}

Simultaneous tracing of direct and trophic Cd bio-accumulation oyster tissues using two stable $\mathrm{Cd}$ isotopes was successful. In fact, ${ }^{110} \mathrm{Cd}$ and ${ }^{112} \mathrm{Cd}$ enrichment in seawater and algae, respectively, induced rapid, important and precise stable isotope ratio variations in oyster tissues, faeces and pseudo-faeces. Cadmium concentrations were determined precisely from modified isotope ratios by isotope dilution calculation adapted to the experimental setup a

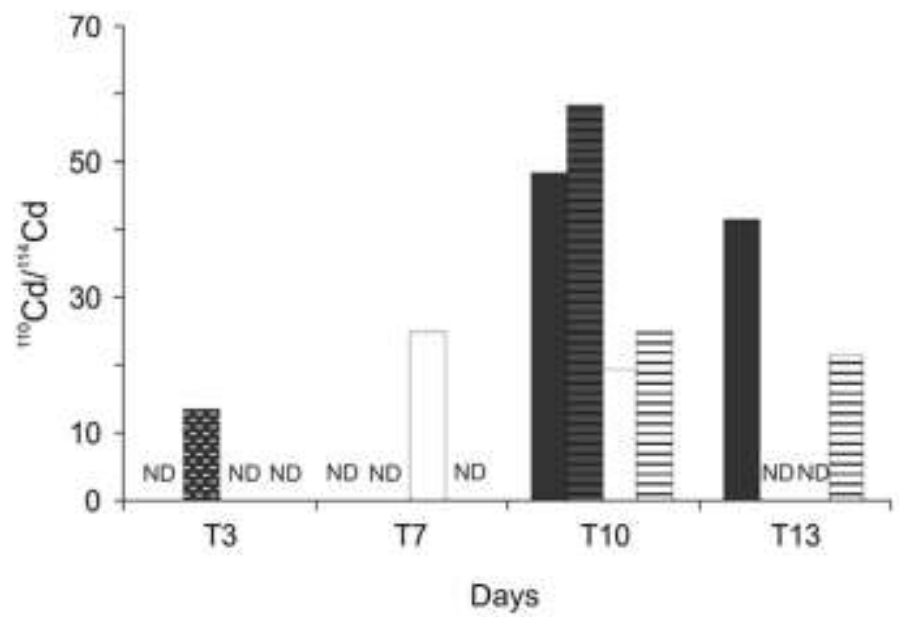

b

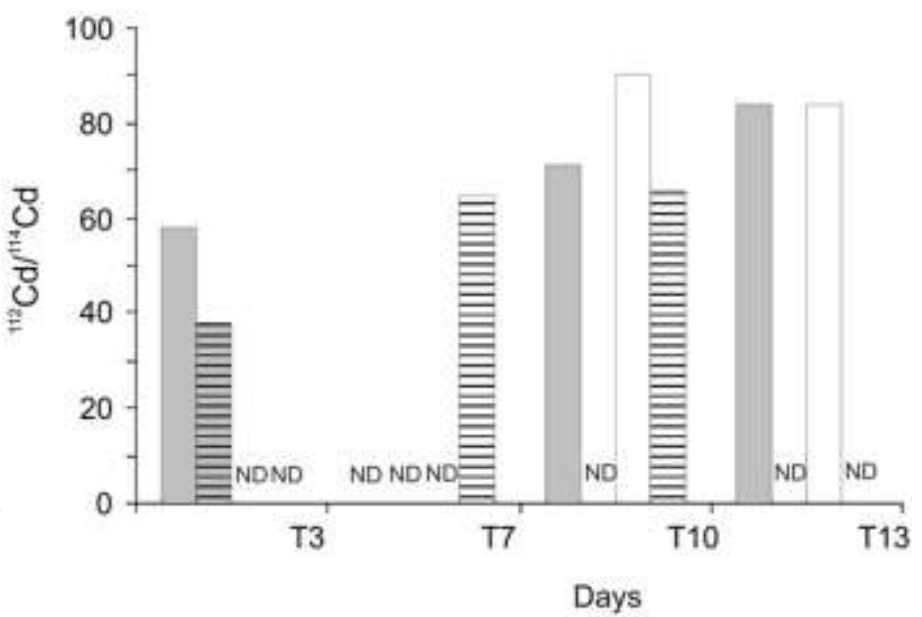

Fig. 3. Stable Cd isotopes ratio variations $\left({ }^{110} \mathrm{Cd} /{ }^{114} \mathrm{Cd}\right.$ and ${ }^{112} \mathrm{Cd} /{ }^{114} \mathrm{Cd}$ ) in faeces (full area) and pseudo-faeces (area with horizontallines) over experiment from Controls units (black area), SeaWater units (dark grey area), Algae units (light grey area) and SeaWater/Algae units (white area). N.D.: not determined.

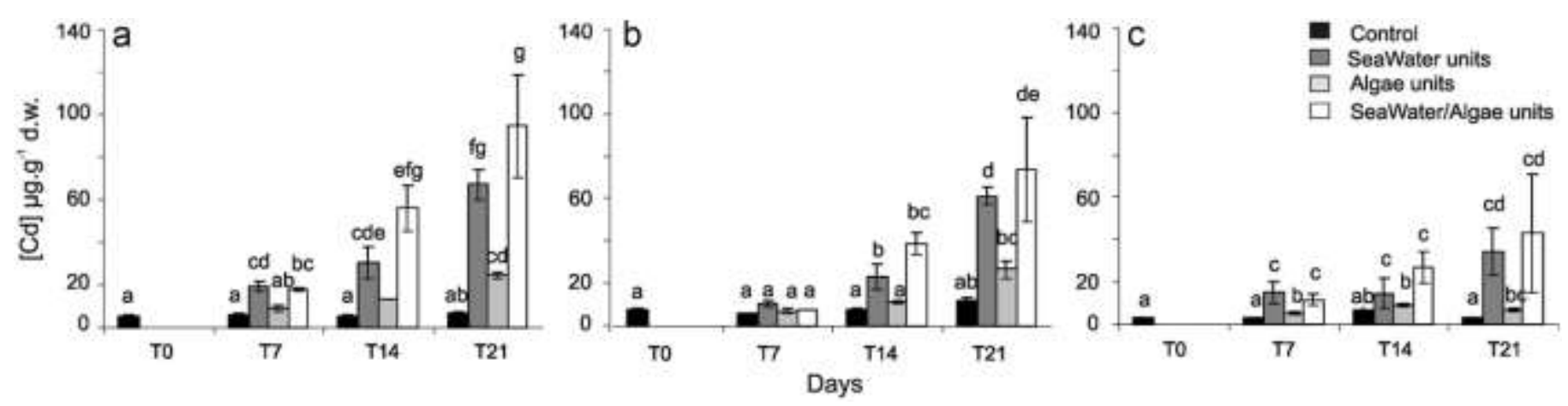

Fig. 4. Bio-accumulated Cd ( $\mathrm{mg} \mathrm{g}^{-1} \mathrm{dw}$, mean 7 SEM (standard errors of means), $n^{1 / 4} 3$ ) in gills (a), digestive glands (b) and rests of bodies (c) over experiment from Controls units (black area), seawater units (dark grey area), algae units (light grey area) and seawater/algae units (white area). Concentrations were measured by ICP-MS and corrected for ${ }^{112} \mathrm{Cd}$ isotopes measured in seawater in SW and SWA units. Letters indicate significant differences between mean values ( $p$ o 0.01 , ANOVA LSD test). 
a

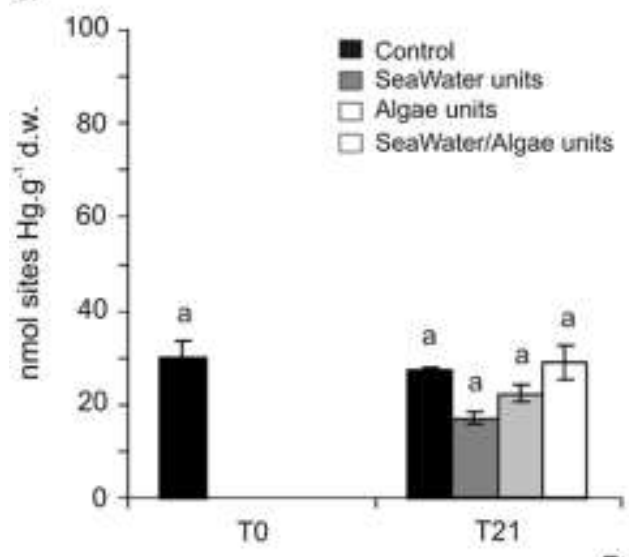

b

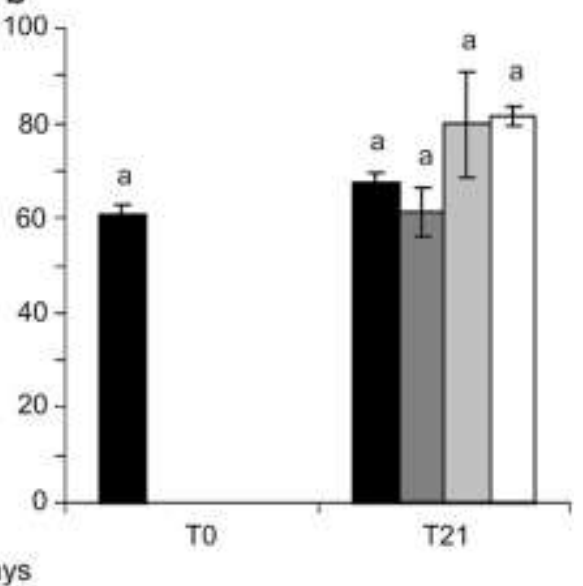

Fig. 5. Metallothioneins concentrations (nmol sites $\mathrm{Hg}^{-1}$ ww, mean 7 SEM, $n^{1 / 4}$ 3) in gills (a) and digestive glands (b) 21 days after exposure from Controls units (black area), Seawater units (dark grey area), Algae units (light grey area) and seawater/algae units (white area). Letters indicate significant differences between mean values ( $p \circ 0.01$, ANOVA LSD test).

(Eq. (2)). The obtained results clearly suggest that the method is well-adapted and that the response obtained is much more sensitive than what would be needed at this exposure level which is only 10 times higher than that in real coastal environments (e.g. Gironde Estuary; (Dabrin et al., 2009). Accordingly, we suggest that the method would be sufficiently sensitive and reliable for lower contamination levels and/or exposure time, comparable to those in previous papers on single stable isotope experiments dealing with direct or trophic contamination of freshwater organisms (Croteau and Luoma, 2007, 2009). One major advantage of simultaneously tracing direct and trophic contamination pathways with two stable isotopes is the possibility of closely following and distinguishing metal pathways and redistribution in different tissues under exactly the same experimental conditions. The tracing technique also enabled us to detect unexpected effects, such as the fact that ${ }^{112} \mathrm{Cd}$ exclusively spiked in the algae also appeared as dissolved metal in seawater of experimental treatments designed to monitor both trophic contamination alone and concomitant direct and trophic contamination. Previous work on T. weissflogii Cd contamination showed that $25-30 \%$ of the metal was cell-surface-adsorbed at this contamination level (using hydroxyquiniline-5-sulphonate; Miao and Wang, 2006). The resulting potential transfer of ${ }^{112} \mathrm{Cd}$ from algae to seawater in $\mathrm{A}$ and SWA treatments would be expected to induce additional direct ${ }^{112} \mathrm{Cd}$ contamination of oyster tissues, which has been corrected using Eq. (7).

\subsection{Direct contamination pathway}

Cadmium bio-accumulation in oyster tissues was more important and faster via the direct than the trophic pathway which is consistent with previous work applying different experimental conditions (Ettajani et al., 2001; Boisson et al., 2003). Kinetics of direct $\mathrm{Cd}$ contamination differed between tissues with accumulation being more efficient and faster in gills than in digestive glands and the rest of the tissues (see Section 3.4.). Tracing direct contamination $\left({ }^{110} \mathrm{Cd}\right.$ in excess) in digestive glands and the rest of the tissues after 7 days of exposure was quite unexpected. In fact, these organs and tissues are not considered closely related to mechanisms involved in direct contamination. Accordingly, ${ }^{110} \mathrm{Cd} /{ }^{114} \mathrm{Cd}$ ratios in digestive glands and the rest of the tissues were attributed to metal redistribution by blood from the most exposed organs (gills) to less affected tissues (digestive glands and the rest of the tissues), as observed in other marine organisms (e.g. eel, Pierron et al., 2008)).

Despite important Cd bio-accumulation, metallothionein concentrations (MT) in gills and digestive glands from oysters contaminated by direct contamination did not increase throughout the experiment (Fig. 5), suggesting that the initially present MT concentrations were sufficient to initiate detoxification processes and decontamination. We remind that oysters were coming from an uncontaminated farming area and were not exposed to high $\mathrm{Cd}$ level before the experiment. This result is clearly different from those of previous accumulation studies where metallothionein production occurred (Ettajani et al., 2001; Marie et al., 2006a, $2006 b)$. This is probably due to the fact that these studies were conducted at concentration levels of $\sim 20 \mathrm{mg} \mathrm{L}^{-1}$, which is $\sim 10$ fold higher than concentration levels in the present study and 100-fold higher than maximum values in the Gironde Estuary (Dabrin et al., 2009),

Cadmium accumulation via the direct pathway was traced in faeces $(\mathrm{F})$ and pseudo-faeces $(\mathrm{PF})$ by significant ${ }^{110} \mathrm{Cd} /{ }^{114} \mathrm{Cd}$ ratio variations (Fig. 3). Since PF and F were immediately removed from the experimental treatment to avoid isotope equilibration with seawater, we assume that ${ }^{110} \mathrm{Cd}$ was transported via blood from gills to $\mathrm{PF}$ and from digestive glands to $\mathrm{F}$. These assumptions are in accordance with increasing isotope ratios measured from T3 to T10, and with a stronger shift in $\mathrm{PF}$ than in $\mathrm{F}$, probably reflecting higher ${ }^{110} \mathrm{Cd}$ levels accumulated in gills than in digestive glands (Fig. 3). Thus, excretion with PF and F can be considered as one pathway of $\mathrm{Cd}$ elimination from gills and digestive glands. However, under the experimental conditions we could not quantify Cd excretion, due to the low recoveries of $\mathrm{F}$ and $\mathrm{PF}$.

\subsection{Trophic contamination in oysters}

Tracing trophic contamination showed ${ }^{112} \mathrm{Cd}$ bio-accumulation in digestive glands, gills and in the rest of the oysters after 14 days of exposure (Fig. 4). Detecting trophic contamination in gills and the rest of the tissues was quite unexpected (Nassiri, 1995) and was attributed to $\mathrm{Cd}$ redistribution between organs by internal mechanisms, as already discussed for direct contamination. Oysters were dissected at least $24 \mathrm{~h}$ after feeding to avoid algae from remaining in the gills. Although one cannot exclude that $\mathrm{Cd}$ weakly bound to algae as remaining cell-adsorbed $\mathrm{Cd}$ (Miao and Wang, 2006) could be adsorbed on gill membranes, Cd desorption by seawater in A and SWA treatments (see discussion above) would 
a

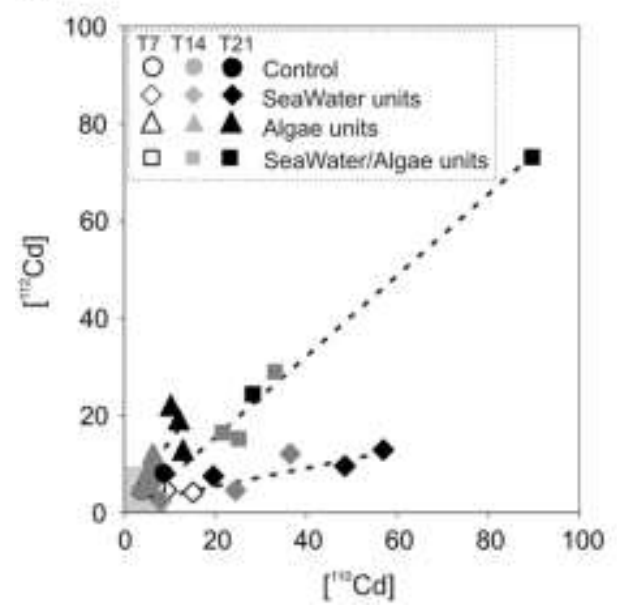

b

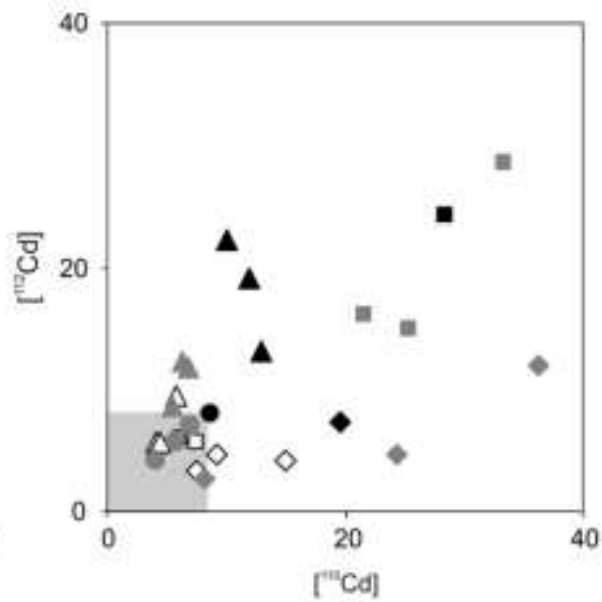

Fig. 6. (a) Mean $\left[{ }^{110} \mathrm{Cd}\right]$ concentration (direct contamination) over mean $\left[{ }^{112} \mathrm{Cd}\right]$ concentration (trophic contamination) measured in digestive glands of oysters from Control, SeaWater unit, Algae units and SeaWater/Algae units after 7, 14 and 21 days of experiment. (b) Zoom of (a). The grey area represents the natural variation content of $\left[{ }^{110} \mathrm{Cd}\right]$ and $\left[{ }^{112} \mathrm{Cd}\right]$ in oysters from Control.

be expected to represent the major desorbable fraction and has been corrected (Eq. (7)). Kinetics of bio-accumulation in digestive glands were lower for trophic than for direct pathways. From the start of the experiment to 7 days of exposure, we measured at the same time an increasing ${ }^{112} \mathrm{Cd} /{ }^{114} \mathrm{Cd}$ ratio in $\mathrm{F}$ (T3; Fig. 3) and an unchanged ${ }^{112} \mathrm{Cd} /{ }^{114} \mathrm{Cd}$ ratio in digestive glands (T7; Fig. 2). Furthermore, at this exposure level, $\mathrm{Cd}$ in T. weissflogii algae is expected to consist of $\sim 30 \%$ soluble $\mathrm{Cd}, \sim 45 \%$ insoluble $\mathrm{Cd}$ and $\sim 25 \%$ adsorbed Cd (Miao and Wang, 2006). This may suggest Cd elimination via excretion rather than adsorption/absorption by stomach and gut membranes (Fisher et al., 1996). From T7 to T14, the ${ }^{112} \mathrm{Cd} /{ }^{114} \mathrm{Cd}$ ratio in digestive glands increased (Fig. 2), whereas it remained constant in F (Fig. 3), suggesting the concomitance of both $\mathrm{Cd}$ absorption by membranes and $\mathrm{Cd}$ elimination. Finally, from $\mathrm{T} 14$ to $\mathrm{T} 21$, the ${ }^{112} \mathrm{Cd}$ accumulated in digestive glands increased considerably (Fig. 4), suggesting more efficient $\mathrm{Cd}$ absorption by membranes. Metallothionein concentrations in the digestive gland remained constant over time (Fig. 5), indicating that no metallothionein-based decontamination mechanisms were induced in response to the exposure level within three weeks. The trophic uptake proportion of $\mathrm{Cd}$ in oysters was estimated at $1 \%$ during the experiment. We determined this uptake rate by estimating the accumulated ${ }^{112} \mathrm{Cd}$ in whole oyster tissues, which is the amount of ${ }^{112} \mathrm{Cd}$ in accumulated oysters from algae minus that in oysters from Control treatments, divided by the supplied enriched ${ }^{112} \mathrm{Cd}$ algae. Previous studies have shown that trophic transfer of $\mathrm{Cd}$ in oysters depends on algae species and exposure level (Nassiri, 1995; Ettajani et al., 2001). In fact, at the $20 \mathrm{mg} \mathrm{L}^{-1} \mathrm{Cd}$ exposure level the trophic transfer to oysters was $\sim 9 \%$ for Skeletonema costatum and 20\% for Tetraselmis suecica, whereas at the extremely high level of $200 \mathrm{mg} \mathrm{L}^{-1}$ it was $\sim 5 \%$ for both species. Thus, by comparing studies, we can conclude that trophic Cd transfer in oysters mainly depends on algae species and that the exposure level appeared to be less significant which is consistent with trophic transfer studies conducted on mussel contamination (Wang and Fisher, 1996; Reinfelder et al., 1997; Arifin and BendellYoung, 2000).

\subsection{Simultaneous direct and trophic contamination in oysters}

One of the most promising characteristics of stable isotope spike experiments is the possibility of independently tracing simultaneous direct and trophic contamination (see SWA treatments, assuming non-interaction between the two uptake routes of exposure). Isotope ratios and bio-accumulation kinetics observed for oysters exposed to both enriched seawater and algae were similar to those observed for direct-only or trophic-only exposure (Figs. 2 and 5). Plotting the direct contamination $\left[{ }^{1{ }^{10}} \mathrm{Cd}\right]$ over the trophic contamination $\left[{ }^{112} \mathrm{Cd}\right]$ measured in digestive glands from oysters from all experimental treatments highlights the role of different contamination pathways over time, clearly showing different trophic and direct contamination kinetics (Fig. 6). Furthermore, the 'SWA treatments' distribution was equivalent to the sum of $\mathrm{Cd}$ accumulated separately via the two pathways (Fig. 6a), even at the beginning of the experiment at low $\mathrm{Cd}$ accumulation (Fig. 6b). These results may suggest (i) that internal metal redistribution mechanisms were similar, when oysters were contaminated via one or both pathways and (ii) the absence of positive or negative feedback between the different contamination pathways under the present experimental conditions. Interestingly, metallothionein levels in gills and digestive glands were again constant at the end of the experiment, even for the highest level of accumulated Cd (Fig. 5).

\section{Conclusions}

Multiple stable isotope spike experiments are a reliable and efficient tool for simultaneously tracing contamination pathways in marine organisms under realistic experimental conditions. The respective contributions of direct and trophic contamination in gills, digestive glands, and in the rest of the bodies were clearly identified, showing that under the experimental conditions, gills and digestive glands were mainly contaminated by direct exposure. Accumulation kinetics in the juvenile oyster tissues changed over time, leading to relatively high $\mathrm{Cd}$ accumulation and redistribution between tissues. Constant metallothionein concentrations along the experiment suggest that the initially present metallothionein levels in the oysters were sufficient to deal with the experimental $\mathrm{Cd}$ exposition. To conclude, tracing contamination pathways by multiple stable isotope spikes was successful for $\mathrm{Cd}$ in oysters and can be transposed to other marine organisms for trace metals with at least three stable isotopes that may be measured in seawater. In perspective, the sensitive responses obtained at the concentration levels used in this work clearly suggest that the present method is suitable at even lower (i.e. environmental) concentration levels in seawater. 


\section{Acknowledgments}

The authors thank Cécile Bossy and Re'gine Maury-Brachet for their advice during metal isotope analysis and GF-AAS measurements, respectively, and Catherine Pham for her English revising Funding was provided by the INSU EC2CO CYTRIX VOTR'TRAM Project, Project 'Region Aquitaine RRLA' and a grant from the French Ministry of Research.

\section{References}

Arifin, Z., Bendell-Young, L.I., 2000. Influence of a selective feeding behaviour by the blue mussel Mytilus trossulus on the assimilation of ${ }^{109} \mathrm{Cd}$ from environmentally relevant seston matrices. Mar. Ecol. Prog. Ser. 192, 181-193.

Audry, S., Blanc, G., Scha" fer, J., Guerin, F., Masson, M., Robert, S., 2007. Budgets of Mn, $\mathrm{Cd}$ and $\mathrm{Cu}$ in the macrotidal Gironde Estuary (SW France). Marine Chemistry $107,433-448$.

Baudrimont, M., Scha"fer, J., Marie, V., Maury-Brachet, R., Bossy, C., Boudou, A., Blanc, G., 2005. Geochemical survey and metal bioaccumulation of three bivalve species (Crassostrea gigas, Cerastoderma edule and Ruditapes philippinarum) in the Nord Me doc salt marshes (Gironde estuary, France). Sci. Total Environ. 337 265-280.

Bendell, L.I., Feng, C., 2009. Spatial and temporal variations in cadmium concentrations and burdens in the Pacific oyster (Crassostrea gigas) sampled from the Pacific north-west. Mar. Pollut. Bull. 58, 1137-1143.

Boisson, F., Goudard, F., Durand, J.P., Barbot, C., Pieri, J., Amiard, J.C., Fowler, S.W., 2003. Comparative radiotracer study of cadmium uptake, storage, detoxification and depuration in the oyster Crassostrea gigas: potential adaptive mechanisms. Mar. Ecol. Prog. Ser. 254, 177-186.

Boutier, B., Chiffoleau, J.,Jouanneau, J.,Latouche, C., Phillips, I., 1989. Lacontamination de la Gironde par le cadmium: origine, extension, importance. Scientific and Technical Report, Ifremer no. 14.

Bragigand, V., Berthet, B, Amiard, J.C Rainbow, P.S., 2004. Estimates of trace metal bioavailability to humans ingesting contaminated oysters. Food Chem. Tox. 42, 1893-1902.

Brinza, L., Nyga ${ }^{\circ}$ rd, C.A., Dring, M.J., Gavrilescu, M., Benning, L.G., 2009. Cadmium tolerance and adsorption by the marine brown alga Fucus vesiculosus from the Irish Sea and the Bothnian Sea. Bioresour. Technol. 100, 1727-1733.

Cheng, W.W.L., Gobas, F.A.P.C., 2007. Assessment of human health risks of consumption of cadmium contaminated cultured oysters. Human Ecol. Risk Assess. 13, 370-382.

Christie, J.C., Bendell, L.I., 2009. Sources of dietary cadmium to the Pacific oyster Crassostrea gigas. Mar. Environ. Res. 68, 97-105.

Copes, R., Clark, N.A., Rideout, K., Palaty, J., Teschke, K., 2008. Uptake of cadmium from Pacific oysters (Crassostrea gigas) in British Columbia oyster growers. Environ. Res. 107, 160-169.

Croteau, M.N., Luoma, S.N., 2007. Characterizing dissolved $\mathrm{Cu}$ and Cd uptake in terms of the biotic ligand and biodynamics using enriched stable isotopes. Environ. Sci. Technol. 41, 3140-3145.

Croteau, M.N., Luoma, S.N., 2009. Predicting dietborne metal toxicity from metal influxes. Environ. Sci. Technol. 43, 4915-4921.

Croteau, M.N., Luoma, S.N., Pellet, B., 2007. Determining metal assimilation efficiency in aquatic invertebrates using enriched stable metal isotope tracers. Aquat. Toxicol. 83, 116-125.

Croteau, M.N., Luoma, S.N., Topping, B.R., Lopez, C.B., 2004. Stable metal isotopes reveal copper accumulation and loss dynamics in the freshwater bivalve Corbicula. Environ. Sci. Technol. 38, 5002-5009.

Dabrin, A., Scha" fer, J., Blanc, G., Strady, E., Masson, M., Bossy, C., Castelle, S., Girardot, N., Coynel, A., 2009. Improving estuarine net flux estimates for dissolved cadmium export at the annual timescale: application to the Gironde Estuary. Estuarine Coastal Shelf Sci. 84, 429-439.

Danielsson, L.G., Magnusson, B., Westerlund, S., Zhang, K., 1982. Trace metal determinations in estuarine waters by electrothermal atomic absorption spectrometry after extraction of dithiocarbamate complexes into freon. Anal. Chim. Acta 144, 183-188.

Dupuy, C., Vaquer, A., Lam-Hoai, T., Rougier, C., Mazouni, N., Lautier, J., Collos, Y., L Gall, S., 2000. Feeding rate of the oyster Crassostrea gigas in a natural planktonic community of the Mediterranean Thau Lagoon. Mar. Ecol. Prog. Ser. 205, 171184.

Ettajani, H., Berthet, B, Amiard, J.C. Chevolot, L., 2001. Determination of cadmium partitioning in microalgae and oysters: contribution to the assessment of trophic transfer. Arch. Environ. Contam. Toxicol. 40, 209-221.

Fisher, N.S., Teyssie' , J.L., Fowler, S.W., Wang, W.X., 1996. Accumulation and retention of metals in mussels from food and water: a comparison under field and laboratory conditions. Environ. Sci. Technol. 30, 3232-3242.

Jouanneau, J.M., Boutier, B., Chiffoleau, J.F., Latouche, C., Philipps, I., 1990. Cadmium in the Gironde fluvioestuarine system: behaviour and flow. Sci. Total Environ. 97-98, 465-479.

Komjarova, I., Blust, R., 2008. Multi-metal interactions between $\mathrm{Cd}, \mathrm{Cu}, \mathrm{Ni}, \mathrm{Pb}$ and $\mathrm{Zn}$ in water flea Daphnia magna, a stable isotope experiment. Aquat. Toxicol. 90, $138-144$.

Lapaquellerie, Y., Jouanneau, J.M., Maillet, N., Latouche, C., 1995. Cadmium pollution in sediments of the Lot river (France), estimate of the mass of cadmium. Pollution en Cd dans les sé diments du Lot (France) et calcul du stock de polluant. Environ. Technol. 16, 1145-1154

Lekhi, P., Cassis, D., Pearce, C.M., Ebell, N., Maldonado, M.T., Orians, K.J., 2008. Role of dissolved and particulate cadmium in the accumulation of cadmium in cultured oysters (Crassostrea gigas). Sci. Total Environ. 393, 309-325.

Malet, N., Sauriau, P.G., Ryckaert, M., Malestroit, P., Guillou, G., 2008. Dynamics and sources of suspended particulate organic matter in the Marennes-Ole ron oyster farming bay: insights from stable isotopes and microalgae ecology. Estuarine Coastal Shelf Sci. 78, 576-586.

Marie, V., 2005. Etude de la réponse des mé tallothione' ines chez les bivalves, Corbicula fluminea, Dreissena polymorpha et Crassostrea gigas, apre'sexposition au cadmium et au zinc. Approches in situ et expe rimentales. Ph.D. Thesis, Universite` Bordeaux1, p. 461

Marie, V., Gonzalez, P., Baudrimont, M., Bourdineaud, J.P., Boudou, A., 2006a. Metallothionein response to cadmium and zinc exposures compared in two freshwater bivalves, Dreissena polymorpha and Corbicula fluminea. BioMetals 19 , 399-407.

Marie, V., Gonzalez, P., Baudrimont, M., Boutet, I., Moraga, D., Bourdineaud, J.P., Boudou, A., 2006b. Metallothionein gene expression and protein levels in triploid and diploid oysters Crassostrea gigas after exposure to cadmium and zinc. Environ. Toxicol. Chem. 25, 412-418.

Miao, A.J., Wang, W.X., 2006. Cadmium toxicity to two marine phytoplankton under different nutrient conditions. Aquat. Toxicol. 78, 114-126.

Nadella, S.R., Fitzpatrick, J.L, Franklin, N., Bucking, C., Smith, S., Wood, C.M., 2009. Toxicity of dissolved $\mathrm{Cu}, \mathrm{Zn}, \mathrm{Ni}$ and $\mathrm{Cd}$ to developing embryos of the blue musse (Mytilus trossolus) and the protective effect of dissolved organic carbon. Comp. Biochem. Physiol. Toxicol. Pharmacol. 149, 340-348.

Nassiri, Y., 1995. Approche par microscopie electronique atransmission analytique des me canismes de toxicite' et de bio-accumulation du cadmium et du cuivr chez Skeletonema costatum, Tetraselmis suecica, Crassostrea gigas. Ph.D. Thesis, Universite' de Nantes.

Ng, T.Y.T., Chuang, C.Y., Stupakoff, I., Christy, A.E., Cheney, D.P., Wang, W.X., 2010 Cadmium accumulation and loss in the Pacific oyster Crassostrea gigas along the west coast of the USA. Mar. Ecol. Progr. Ser. 401, 147-160.

Pierron, F., Baudrimont, M., Lucia, M., Durrieu, G., Massabuau, J.C., Elie, P., 2008. Cadmium uptake by the European eel: trophic transfer in field and experimental investigations. Ecotoxicol. Environ. Saf. 70, 10-19.

Reinfelder, J.R., Wang, W.X., Luoma, S.N., Fisher, N.S., 1997. Assimilation efficiencies and turnover rates of trace elements in marine bivalves: a comparison of oysters, clams and mussels. Mar. Biol. 129, 443-452.

Saratug, S., Garrett, S.H., Sens, M.A., Sens, D.A., 2010. Cadmium, environ- mental exposure and health outcomes. Environ. Health Perspect. 118, 182-199.

Strady, E., Blanc, G., Scha" fer, J., Coynel, A., Dabrin, A., 2009. Dissolved uranium, vanadium and molybdenum behaviours during contrasting freshwater discharges in the Gironde Estuary (SW France). Estuarine Coastal Shelf Sci. 83, $550-560$

Wang, W.X., Fisher, N.S., 1996. Assimilation of trace elements and carbon by the mussel Mytilus edulis: effects of food composition. Limnol. Oceanogr. 41, 197 207.

Widmeyer, J.R., Bendell-Young, L.I., 2008. Heavy metal levels in suspended sediments, Crassostrea gigas, and the risk to humans. Arch. Environ. Contam. Toxicol. $55,442-450$. 